\title{
Diagnosis of plant viruses by nucleic acid hybridization
}

\author{
REIJO KARJALAINEN \\ Department of Plant Pathology, University of Helsinki \\ SF-00710 Helsinki, Finland
}

LEO ROUHIAINEN

Department of Microbiology, University of Helsinki

SF-00710 Helsinki, Finland

HANS SÖDERLUND

Orion Genetic Engineering Laboratory, Valimotie 7

SF-00380 Helsinki, Finland

\begin{abstract}
Nucleic acid hybridization is a powerful technique for the diagnosis of many plant viruses not easily detected by serological techniques. It is particularly effective in the detection of viruses occurring in low amount in plant tissue, viruses that are poor immunogens or contain satellites.

Molecular probes with desired specificities can be prepared by recombinant DNA techniques for large scale use. cDNA probes of potato virus X (PVX) RNA were made by molecular cloning, and the clones were ${ }^{32} \mathrm{P}$ labelled by nick translation. Hybridization of cDNA to PVX RNA revealed $1 \mathrm{ng}$ of purified virus in $2 \mu \mathrm{l}$ spots dried onto nitrocellulose filter. Infected samples of crude leaf extracts were easily detected by hybridization, while probes did not react with healthy leaf samples.

Nucleic acid hybridization research aims at replacing radiometric probes with nonradioactive methods involving enzymes which are directly or indirectly coupled to the probe and whose presence is observed with the aid of a colour changing substrate. Hybridization assay formats that can easily be automatized are under development. Sandwich hybridization is a simple test format developed for analyzing unpurified biological material, and it appears to be a powerful tool for microbial diagnostics. Sensitivity can be improved by using detection systems in which the specific activity of the probe is increased. Procedures such as 'polymerase chain reaction', in which the amount of detectable nucleic acid sequences can be increased, are promising alternatives for increasing sensitivity. It is concluded that even if probe-based assays are in their infancy, they will no doubt develop towards such easy use as have immunological test kits.
\end{abstract}

Index words: virus detection, cDNA probes, potato virus $\mathrm{X}$ (PVX), spot hybridization, sandwich hybridization 


\section{Introduction}

Crop losses caused by plant viruses are currently controlled mainly by using virus-free plant material and disease resistant cultivars (WALKEY 1985). The success of virus disease control is thus crucially dependent on the availability of accurate, sensitive but simple diagnostic techniques which enable the early detection of viral infections in plant material. In many areas of plant production there is a great need for improved procedures for the rapid and sensitive detection of important plant viruses, particularly in laboratories responsible for producing healthy horticultural and field crop plants, in plant quarantee laboratories (SymONS 1984), and plant breeding stations. Different virus diagnostic tools are needed for different purposes. For instance, extremely sensitive and accurate diagnostic techniques are required to detect some viruses in berry plants and other horticultural crops when producing virus-free material because certain viruses occur in low concentration in plant tissue. When producing virus-free potato cultivars or screening breeding material for virus resistance, diagnostic procedures should be rapid but reliable to detect various strains of the target virus because large numbers of samples are analyzed in a short time.

Traditionally, plant virus diagnosis has mainly relied on electron microscopy, immunological analyses, and symptom expression on indicator plants. However, many of these methods are time-consuming and unreliable and thus unsuitable for analyzing large numbers of samples (Symons 1984). Currently, the most widely used serological technique is the ELISA because it is simple and sensitive and appropriate even for small laboratories (review by CLARK and BAR-JOSEPH 1984). However, the ELISA or related serological techniques are not always reliable enough. For instance, some viruses which occur in low concentration in plant tissue (e.g. barley yellow dwarf virus, potato leafroll virus), are poor immunogens or difficult to purify, are not easily detected by serological techniques (Symons 1984, Hull 1986). For some viruses which have a wide host range (e.g. cucumber mosaic virus) and are unstable or contain satellite RNA encapsidated by the coat protein of the associated virus, serological diagnosis is also impossible (HARRISON et al. 1983, Palukaitis et al. 1985). Viroids, the smallest known pathogenic agents of plants, have no protein coat, and are thus not detectable by immunological methods (OwENS and DIENER 1984).

Nucleic acid hybridization is a new, powerful diagnostic alternative for the detection of viral infections in plants (MAULE et al. 1983). Hybridization techniques are based on the ability of complementary single-stranded nucleic acid sequences to hybridize under appropriate conditions. Because of the unique base pairing tendency, hybridization is an attractive method since it is highly specific, accurate and able to detect very low concentrations of viral nucleic acids in plant extract. Nucleic acid hybridization has become a realistic diagnostic technique in the past few years, when recombinant DNA techniques made it possible to produce complementary nucleic acid probes (cDNA) with desired specificity for large scale use.

Nucleic acid hybridization has been used in the detection of various human viruses and other microbes of clinical importance for several years (review by VISCIDI and YOLKEN 1987), as well as in the detection of some food contaminating microbes (FitTs et al. 1983). It was first shown by OwEns and Diener (1981) that plant viroid infections can be effectively detected by nucleic acid hybridization using cloned cDNA probes. Since then nucleic acid hybridization has been widely tested as a means of diagnosing various plant virus diseases (Hull 1986). However, there are still many problems limiting its wide diagnostic application both in medical and agricultural fields. One serious limitation is the use of radioactively labelled recombinant DNA probes, which are still more reliable than the nonradioactive ones available. However, non- 
radioactive labelling techniques are rapidly being developed (SYvänen et al. 1986, Li et al. 1987).

Progress has also been made in developing hybridization test formats. Sandwich hybridization technique has been developed for the detection of nucleic acids in crude clinical samples (RANKI et al. 1983). In this hybridization method, the specimen is kept in solution, and thus sample pretreatments are easy and background problems can be reduced. Sandwich hybridization has been used to diagnose various viral and bacterial infections during the past five years (RANKI et al. 1987), and its value in the detection of plant viral infections is being evaluated.

This paper is a review of recent developments in nucleic acid hybridization and its applications for plant virus diagnostics. The use of hybridization techniques is illustrated using potato virus $\mathrm{X}(\mathrm{PVX})$ as a test virus.

\section{Methodological aspects}

In principle, the use of hybridization techniques for the detection of plant viruses is rather simple. The first step is to prepare labelled complementary DNA (cDNA) to the target viral nucleic acid. In the case of dotblot (sap spot) hybridization, a small amount of plant extract is immobilized on a solid support, usually nitrocellulose or nylon filter, and the labelled cDNA probe is added and incubated with it. As both samples are rendered single-stranded, the probe will hybridize with homologous sequences in the plant extract on the support. The extent of hybrid formation is a measure of the concentration of viral sequences in the plant extract, which can be visualized on the filter by autoradiography.

Although most plant viruses contain RNA genomes, RNA probes are relatively little used in nucleic acid hybridization diagnostics. Viral RNA to be used as end-labelled RNA probes can be prepared from ssRNA isolated from purified virions or from dsRNA replicative forms (GARger and TURPEN 1986). RNA probes can also be conveniently made in vitro using RNA polymerase and cloned cDNA in plasmid vectors with RNA polymerase promoter sites (Melton et al. 1984).

The use of synthetic oligonucleotides is a rapid hybridization method. Several synthetic probes have been used to diagnose various viral and bacterial infections (HILL et al. 1985, Lin et al. 1987). However, synthetic oligonucleotide probes have not been much used in plant virus diagnostics because of the lack of published sequence information and partly because of their poor sensitivity (BARJosepH et al. 1986).

Complementary DNA (cDNA) to viral genomic RNA is the most widely used type of probe in nucleic acid hybridization. There are several techniques for its preparation. In general, these techniques involve four steps (Palukaitis 1986): 1. the cDNA synthesis reaction, 2. the separation of the cDNA from the template and the enzyme, 3 . the separation of the cDNA from the unincorporated radioisotope and other components of the reaction mixture, and 4 . the concentration of the cDNA probe. The appropriate method depends on the properties of the virus, its molecular weight, structure, and 3' polyadenylate sequences. The majority of plant viruses contain single-stranded RNA genomes, and only a small percentage contains DNA (HuLL and DAvies 1983).

In this paper, potato virus $\mathrm{X}$ (PVX) was used as a test virus to prepare a cDNA probe and to use it for detecting plant viral infections.

\section{Cloning strategies and preparation of $c D N A$ probes of $P V X R N A$}

Potato virus X (PVX) is world-wide distributed in potato growing countries, and it is estimated that tuber yields of infected plants can be reduced by 5-15\% (TORRANCE et al. 1986). The virus causes mild mosaic on potato leaves, but foliage symptoms are not reliable indications of infection (TORRANCE et al. 1986). Several strains of PVX can be distinguished, but in some cases they are not 
easily detected by serological assays based on polyclonal antibodies (Moreira et al. 1980). In order to reveal their serological relationships in more detail, monoclonal antibodies have been produced from two strains of PVX (Koenig and Torrance 1986, Torrance et al. 1986).

PVX is a potexvirus containing singlestranded RNA. Its molecular weight is $2.1 \times$ $10^{6}$, and its coding capacity is sufficient for three polypeptides (Morozov et al. 1983). Recently, Morozov et al. (1983) showed that the RNA of PVX has a poly-A tail of about $50-200$ bases at its 3' end, and there is a cap $\mathrm{m}^{7}$ GpppG at the 5' end. Part of PVX RNA has been sequenced, and its amino acid sequence has been deduced from nucleotide sequences (Morozov et al. 1983).

\section{Virus purification and RNA extraction}

The PVX isolate used in this work was originally isolated by Dr. A. Kurppa. The virus was purified from infected Nicotiana glutinosa leaves, mainly according to SHEPHARD (1972), but further purification was made by centrifugation into $\mathrm{CsCl}$ gradient. The viral RNA was treated with $0.5 \%$ SDS and phenol extracted, then precipitated with ethanol. Purity of the RNA was analyzed spectrophotometrically and by agarose gel electrophoresis.

\section{cDNA synthesis and molecular cloning}

Complementary DNA (cDNA) to the genomic RNA of PVX was synthesized by the method of Gubler and Hoffman (1983). In general, first-strand cDNA was synthesized by AMV reverse transcriptase (Promega Biotech) using oligo-dT as a primer and the polyadenylated RNA of PVX as a template. The second strand of cDNA was synthesized with DNA polymerase I.

Double-stranded cDNA was digested with Sau 3 and cloned into the plasmid pBR322 at the BamHI site. Recombinant clones were identified on the basis of their sensitivity or resistance to tetracycline and ampicillin. The clones were screened for the size of cDNA insert by agarose gel electrophoresis, and those containing inserts larger than 500 bases were selected for hybridization studies. The cDNA probes were labelled by nick-translation to a specific activity of approximately $10^{8}$ $\mathrm{cpm} / \mu \mathrm{g}$.

\section{Sample preparation and hybridization}

For hybridization, $2 \mu \mathrm{l}$ of crude leaf sap extract or purified virus was spotted onto nitrocellulose filters, which were first soaked in water and then in $20 \times \mathrm{SSC}$. The filters were baked at $80^{\circ} \mathrm{C}$ for $2 \mathrm{~h}$ in a vacuum oven.

The filters were prehybridized in a waterbath at $45^{\circ} \mathrm{C}$ for $4-5 \mathrm{~h}$ using sealed plastic bags and then hybridized at $50^{\circ} \mathrm{C}$ for about $16 \mathrm{~h}$. The hybridization buffer contained denatured ${ }^{32} \mathrm{P}$ labelled cDNA at a concentration of approximately $30 \mathrm{ng} / \mathrm{ml}$. After hybridization, the filters were washed four times at room temperature for $5 \mathrm{~min}$ and twice at $50^{\circ} \mathrm{C}$ for $15 \mathrm{~min}$ in $0.1 \mathrm{SSC}+0.2 \% \mathrm{SDS}$. Then filters were autoradiographed at $-80^{\circ} \mathrm{C}$ for $24 \mathrm{~h}$.

The cDNA clone 19 of PVX RNA used as the reference probe was a kind gift of Dr. D. Baulcombe, Plant Breeding Institute, Cambridge.

\section{Preparation of reagents for sandwich hybridization}

The sandwich hybridization method is based on two separate nucleic acid reagents, which are derived from two non-overlapping but adjacent regions of the target microbial genome (RANKI et al. 1983). One of the fragments is immobilized on a nitrocellulose filter in single-stranded form (filter-DNA), and the other fragment is radioactively labelled (probeDNA). In the reaction any nucleic acid sequence homologous to the DNA reagents will hybridize both to the filter-DNA and to the probe-DNA, thus binding the probe to the filter (RANKI et al. 1983). In this system, the reagents have no common sequences, there- 
fore no hybrids are formed with incorrect sample nucleic acids.

In general, the preparation of nucleic acid fragments for sandwich hybridization involves various molecular biological techniques (Fig. 1). Various restriction enzymes are usually first used to map the target DNA fragment, and then two adjacent restriction fragments are subcloned into two different vectors. DNA fragments for filter-DNA are subcloned into the plasmid vector pBR322 or its derivative pAT153 (RANKI et al. 1983). Single-stranded probe-DNA is cloned in the bacteriophage M13. In the case of subcloning of reagent pairs of starter cDNA of PVX for sandwich hybridization, the size of filter-DNA was $150 \mathrm{bp}$, and for the probe-DNA $700 \mathrm{bp}$ was used.

As in the spot hybridization described previously, double-stranded recombinant plasmid DNA is denatured in $0.2 \mathrm{M} \mathrm{NaOH}$ at $100^{\circ} \mathrm{C}$ for $5 \mathrm{~min}$, cooled at $0^{\circ} \mathrm{C}$, and applied to the nitrocellulose filter in ice-cold $6 \times \mathrm{SSC}$ under slight pressure, then fixed onto the filter by baking under vacuum at $80^{\circ} \mathrm{C}$ for $2 \mathrm{~h}$ (RAN$\mathrm{KI}$ et al. 1983). In sandwich hybridization reaction, each hybridization contains one filter with microbe-specific DNA and one or two control filters with calf thymus or no DNA, respectively (RANKI et al. 1983). Incubation is usually allowed to proceed overnight (16$20 \mathrm{~h})$ at $65^{\circ} \mathrm{C}$, after which the filters are carefully washed. Hybrid formation is quantitatively measured by a radioactivity counter (RANKI et al. 1983).

\section{Applications for virus detection}

cDNA cloning of PVX RNA revealed three distinct types of inserts after Sau3 digestion (Fig. 2). Of these inserts, the one of $850 \mathrm{bp}$ was selected as the test clone, called clone PVX 59, to demonstrate the use of cloned cDNA probes for detecting plant viral infections. After mass production of the plasmid in $E$. coli cells, it was labelled with ${ }^{32} \mathrm{P}$ by nick-translation. original DNA to be cleaved

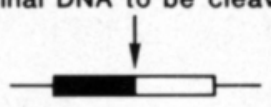

cloning into different vectors

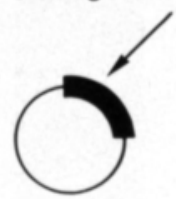

immobilization on filter

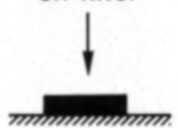

detection of target DNA
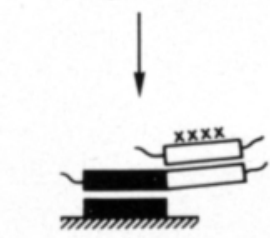

SANDWICH HYBRID

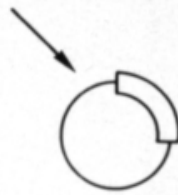

labelling

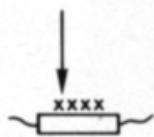

no detection of unrelated DNA

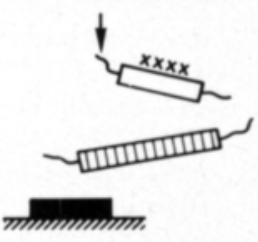

NO HYBRIDIZATION
Fig. 1. Principle of sandwich hybridization assay.

In the first test, the ${ }^{32} \mathrm{P}$-labelled cDNA probe was used to detect purified PVX virus. It was found (Fig. 3) that this probe of 850 bp complementary to PVX RNA easily revealed as little as $1 \mathrm{ng}$ of purified virus containing $50 \mathrm{pg}$ of RNA by hybridization to 2 $\mu \mathrm{l}$ spots dried onto nitrocellulose filters. In the second test, dilution series of crude extract from infected tobacco leaves indicated that dilutions with water of up to 500 times were readily detectable by hybridization autoradiographed for $24 \mathrm{~h}$ (Fig. 4). In addition, an experiment was carried out where 36 sap samples $(2 \mu \mathrm{l})$, including random samples, infected and healthy potato leaves, were spotted onto filter. The results showed (Fig. 5) that infected samples were easily detected by cDNA probe.

The results presented here showed that cDNA hybridization is a reliable way of detecting PVX infections in crude plant sap. The sensitivity of our cDNA probes appears to be 
clone pPVX 59

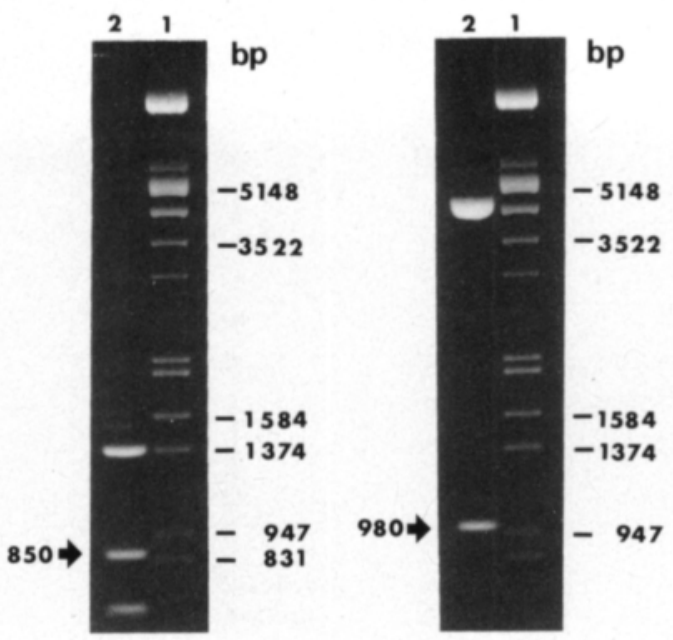

Fig. 2. Agarose gel electrophoresis of fragments of the pPVX 59 and pPVX 19 clones. Clone 59 (lane 2) was cut with Sau3A, clone 19 (lane 2) with PstI, and the DNA markers (lane 1) with HindIII + EcoRI. The arrow indicates the position of PVX cDNA inserts.

\section{pPVX 59 pPVX 19}
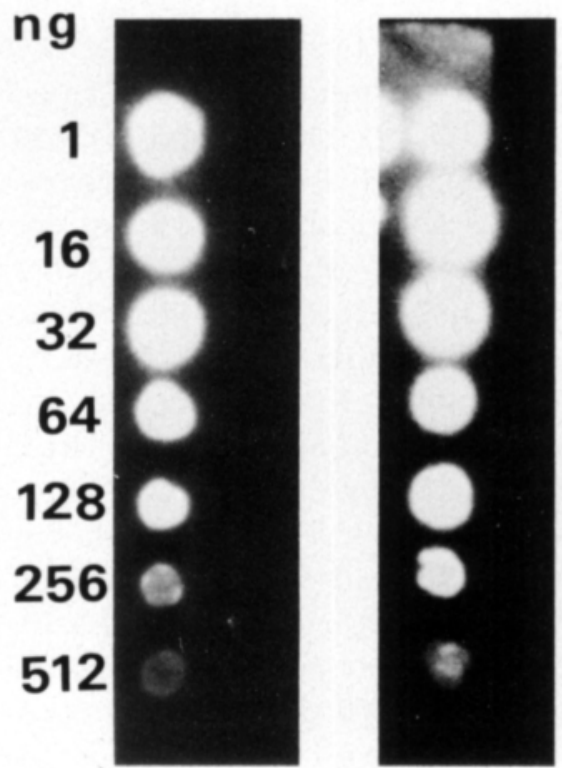

ng

1

16

32

64

128

256

512

Fig. 4. Dot blot from crude sap dilutions of $N$. glutinosa leaves infected with PVX. The clones were ${ }^{32} \mathrm{P}$ labelled by nick-translation. $24 \mathrm{~h}$ exposure.

\section{clone}

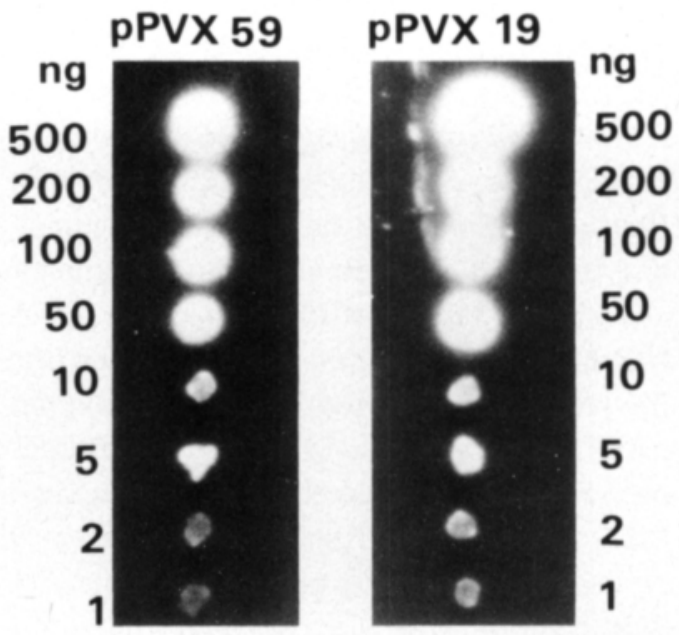

Fig. 3. Dot blot hybridization of purified PVX with ${ }^{32} \mathrm{P}$-labelled, nick-translated probes of pPVX 19 and pPVX 59. $24 \mathrm{~h}$ exposure.

\section{clone pPVX 59}
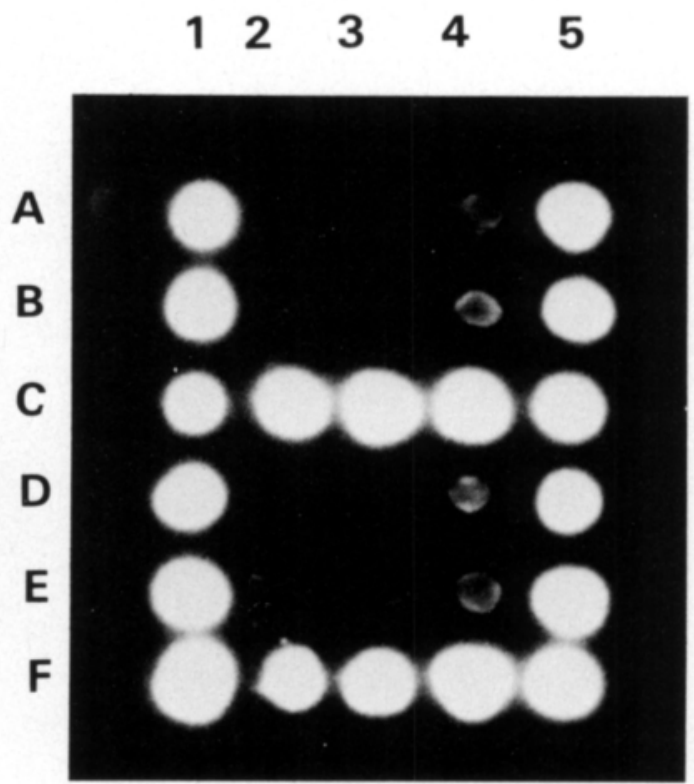

Fig. 5. Detection of PVX in sap extracts. $2 \mu \mathrm{l}$ samples of sap from infected, healthy, and randomly taken leaves were spotted onto nitrocellulose filter. After $24 \mathrm{~h}$ exposure, samples containing viral RNA (lanes $1,4,5$, spots $2 \mathrm{C}, 3 \mathrm{C}, 2 \mathrm{~F}$ and $3 F)$ were easily detected. 
of the same order as detected by BAULCOMBE et al. (1984). In general, cDNA hybridization seems to be as sensitive as the ELISA or even more sensitive to detect PVX infections in plants (Boulton et al. 1984). Hybridization has been found to be an efficient way of screening large numbers of potato clones for resistance to PVX. Boulton et al. (1984, 1986) have pointed out that $\mathrm{CDNA}$ probes require less sap and fewer manipulations than the ELISA, and they are more rapid for screening large numbers of clones for PVX infections in a few days than the ELISA. However, PVX is highly immunogenic and occurs abundantly in plant tissue, and it is in most cases easily detectable by standard ELISA techniques (Goodwin and BANTTARI 1984). It has been suggested that antisera against certain strains of PVX cannot always detect all strains (MoREIRA et al. 1980). In these cases, alternative strategies using either monoclonal antibodies (Torrance et al. 1986) or cDNA probes carefully prepared from certain regions of the PVX genome (BAUlcombe et al. 1984) can be useful diagnostic tools and also reveal the strain diversity of PVX.

Within the past three years nucleic acid hybridization has been increasingly used for the detection of plant virus infections. For example, cDNA probes have been produced from various virus groups (Table 1), including large potyviruses, potexviruses, closteroviruses, luteoviruses, and the Fiji disease virus belonging to the small group of reoviruses. cDNA probes are not only sensitive for detecting some viruses which occur in high amounts in plant tissue, e.g. TMV and PVX, but also a powerful way of diagnosing viruses such as tobacco rattle (HARRISON et al. 1983, HuUB et al. 1986), which infect large numbers of different agricultural and horticultural crops and which are not reliably detected by serological techniques. In addition, it has been recently shown that cDNA techniques are effective in diagnosing viruses which occur in low concentration in plant tissue, such as the economically very important barley yellow dwarf (HABILI et al. 1987) and the Fiji disease

Table 1. Some of the cDNA probes prepared from different plant viruses as reported by various authors.

\begin{tabular}{|c|c|c|c|}
\hline Virus group & Virus & $\begin{array}{l}\text { Viral } \\
\text { nucleic acid }\end{array}$ & Reference \\
\hline Luteoviruses & $\begin{array}{l}\text { Barley yellow dwarf virus (BYDV) } \\
\text { Subterranean clover red leaf virus } \\
\text { (CRLV) } \\
\text { Potato leafroll virus (PLRV) }\end{array}$ & $\begin{array}{l}\text { ssRNA } \\
\text { SsRNA } \\
\text { SsRNA }\end{array}$ & $\begin{array}{l}\text { WATERHOUSE et al. } 1986 \\
\text { JAYASENA et al. } 1984 \\
\text { BAULCOMBE et al. } 1984\end{array}$ \\
\hline Potyviruses & $\begin{array}{l}\text { Potato virus Y (PVY) } \\
\text { Bean yellow mosaic virus (BYMV) }\end{array}$ & $\begin{array}{l}\text { ssRNA } \\
\text { ssRNA }\end{array}$ & $\begin{array}{l}\text { HAMMOND and HAMMOND } 1985 \\
\text { ROSNER et al. } 1986 \\
\text { DEBOKX and CUPERUS } 1987\end{array}$ \\
\hline Potexviruses & Potato virus X (PVX) & ssRNA & BAutcombe et al. 1984 \\
\hline Tobamoviruses & Tobacco mosaic virus (TMV) & ssRNA & $\begin{array}{l}\text { SELA et al. } 1984 \\
\text { BAR-JoSEPH et al. } 1986\end{array}$ \\
\hline Tobraviruses & Tobacco rattle virus (TRV) & $\begin{array}{l}\text { ssRNA } \\
\text { ( } 2 \text { div.) }\end{array}$ & $\begin{array}{l}\text { HARRISON et al. } 1983 \\
\text { HuUB et al. } 1986\end{array}$ \\
\hline Tombusviruses & Tomato bushy stunt virus (TBSV) & ssRNA & Gallitelli and Hull 1985 \\
\hline Closteroviruses & Citrus tristeza virus (CTV) & ssRNA & ROSNER et al. 1983 \\
\hline Reoviruses & Fiji disease virus (FDV) & dsRNA & SKUTNICKI et al. 1986 \\
\hline Comoviruses & Cowpea mosaic virus (CpMV) & dsRNA & Maule et al. 1983 \\
\hline Geminiviruses & African cassava mosaic virus (ACMV) & ssDNA & RoBinson et al. 1984 \\
\hline Caulimoviruses & $\begin{array}{l}\text { Cauliflower mosaic virus (CaMV) } \\
\text { Figwort mosaic virus (FMV) } \\
\text { Carnation etched ring virus (CERV) }\end{array}$ & $\begin{array}{l}\text { dsDNA } \\
\text { dsDNA } \\
\text { dsDNA }\end{array}$ & $\begin{array}{c}\text { MAULE et al. } 1983 \\
" \\
"\end{array}$ \\
\hline
\end{tabular}


of sugarcane (SKUTNICKI et al. 1986). The present status of the sensitivity of cDNA probes compared with other diagnostic methods is not well demonstrated. Only a few direct comparisons are available between the ELISA and cDNA probes, and in general they suggest that nucleic acid hybridization is at least as sensitive as the ELISA (MAULE et al. 1983) or even more sensitive for the detection of, for example, tobacco mosaic virus (TMV) and potato virus Y (PVY) (SEla et al. 1984, DeBoKx and CuPERUS 1987). The actual limit of sensitivity for the detection of plant viruses using cDNA probes is poorly known. MAULE et al. (1983) showed using ${ }^{32} \mathrm{P}$-labelled probes that the limit of sensitivity for several plant viruses was about $5-20 \mathrm{pg}$ of purified RNA. BAULCOMBE et al. (1984) were able to detect $1 \mathrm{ng}$ of PVX (50 pg RNA) in a $1 \mu \mathrm{l}$ spot. Sensitivity limits for the detection of viroid infection in plant tissue are somewhat better known than those of plant viruses. For example, $80 \mathrm{pg}$ of PSTV (30 ng/g tuber) has been detected (PALUKAlTIS et al. 1985). About $300 \mathrm{pg}$ of avocado sunblotch viroid (ASBV) was detected without any purification (ROSNER et al. 1983), and with partial purification and concentration about $5 \mathrm{pg}$ in $3-5 \mu \mathrm{l}$ spots, which means about $20 \mathrm{pg}$ ASBV/g fresh weight leaf (BARKER et al. 1985).

Sandwich hybridization has been used to diagnose various animal viruses as well as bacterial pathogens (RANKI et al. 1987). Advantages of sandwich hybridization over spot hybridization are that sample pretreatments can be kept simple and crude samples can be tested without causing unspecific hybridization background. Sandwich hybridization has been shown to be as sensitive in adenovirus detection as radioimmunoassay (review by RANKI et al. 1987). So far, however, this technique is just beginning to be applied for the diagnosis of plant viruses.

\section{Prospects for improving nucleic acid hybridization as a diagnostic tool}

Any diagnostic procedures which are likely to be used on a large scale in routine plant virus testing should fulfill a number of criteria. The main requirements are a) specificity, b) sensitivity, c) simplicity to perform, and d) they should not contain decaying reagents.

In nucleic acid hybridization the specificity is an intrinsic advantage. A gene region specific for the organism or group of organisms to be detected can always be found by using recombinant DNA techniques. The cloning of specific viral nucleic acid sequences and the preparation of probes for desired specificity provide powerful tools for the detection of various isolates of the target virus and for the characterization of strain variation.

The sensitivity of nucleic acid based tests appears, in chemical terms, very good. Today the best sensitivity is obtained using ${ }^{32} \mathrm{P}$ labelled probes, in which case down to $2 \times$ $10^{-20}$ moles of target nucleic acid can be found. This corresponds to about 10000 molecules of DNA or RNA (SYVÄNEN 1986). With non-radiometric methods the detection limit is usually reduced several hundred fold. There is, however, usually only one genome per micro-organism and in many applications a test in which e.g. 100000 bacteria per 100 $\mu \mathrm{l}$ is the detection limit, is simply not satisfactory.

A lot of work is done on improving the sensitivity of probe-based tests. One simple way is to assay for a nucleic acid present in many copies per micro-organism. Such multicopy sequences which can be assayed for include ribosomal RNA (Göbel and StANDBridge 1986), multicopy plasmids (TOTTEN et al. 1983), and repetitive DNA sequences in the genome (GonZALES et al. 1984).

Another direct way of improving the tests is to use detection systems in which the specific activity of the probe (i.e. signals generated per mass unit of DNA) is increased over those used presently. This is at least theoretically achievable using time-resolved fluorescence and Europium label (SoINI and KuJALA 1983, SyVÄNEN et al. 1986).

Bioluminescent systems can in principle give extremely high sensitivity (TANAKA and IsHI- 
KAWA 1986), as can coupled multienzyme reactions in which the final detectable product is amplified over the primary one (SELF 1985). The major breakthrough in improving the sensitivity of probe-based tests is, however, found in one of the unique properties of nucleic acids. The very basis of heredity is that DNA is duplicated in dividing cells and can be multiplicated in propagating organisms. Specific regions of DNA can by the same principle be enzymatically amplified in vitro. In a reaction called 'polymerase chain reaction' (SAIKI et al. 1985) a given DNAsequence can be duplicated many times giving an exponential increase in the copies of the target DNA which is then easy to detect by hybridization. Even a few copies of DNA can be detected in this way. The polymerase chain reaction has the potential to solve the sensitivity problem of hybridization-based tests.

Extremely high sensitivity is only seldom required in plant virus diagnostics, perhaps most often in the detection of viruses of berry or woody plants when producing virus-free plant material. When comparing the published data on sensitivity values in detecting plant viruses and those of the potential detection sensitivity provided by nucleic acid hybridization (SYVÄNEN 1986), it is clear that the present probe-based tests are not nearly as sensitive as they could be. This is probably due to the fact that sample treatments are not optimal for obtaining high sensitivity. Using simple pretreatments for plant material and effective extraction buffers, detection sensitivity can be improved (Palukaitis et al. 1985). In addition, slight modifications of procedures, changes in hybridization buffers, for instance, can in some cases considerably improve the sensitivity compared to the original buffer (Palukaitis 1986). However, extra steps complicate procedures, and multistep pretreatments are justified only in cases where virus amounts in plants are low and high sensitivity is necessarily required.

Reaction times in minutes rather than hours or days are often important in diagnostics. Due to low concentrations, hybridization reactions are relatively slow. However, the situation has improved recently. Very high probe concentrations (LEARY et al. 1983), the use of oligonucleotides rather than large probes (JABLONSKI et al. 1986), and volume excluders like dextran sulfate and polyethylene glycol (AmASiNo 1986) have all been important steps in increasing the reaction rate significantly. As hybridization time can be shortened to a few hours without any significant loss of sensitivity by using oligonucleotide probes (LIN et al. 1987), their use in plant viral diagnostics might be useful in cases where speed is more important than high sensitivity. Synthetic probes may be an attractive alternative for the diagnosis of dangerous viroid diseases because they can be prepared without the need of propagating the target organism (BAR-JosePH et al. 1985). Many plant viroids have been sequenced and oligonucleotides could be easily constructed (RIESNER and Gross 1985).

The first generation of probe-based tests is now becoming available for the diagnostics of some micro-organisms. These tests have their roots in the methodology used in research laboratories and their use is still dependent on laboratory surroundings. The development of more convenient assay formats and simple tools and kits is, however, in progress.

One important aspect is the development of non-radioactive probes which do not selfdecay. Several different approaches have been tried to replace ${ }^{32} \mathrm{P}$ or ${ }^{125} \mathrm{I}$ as detectors. One useful method involves enzymes, directly or indirectly coupled to the probe (LEARY et al. 1983, Renz and Kurz 1984, TChen et al. 1984, JABLONSKY et al. 1986, Li et al. 1987), the presence of which is observed with the aid of a colour changing substrate. This approach will lead to tests with certain ELISA-like features. Another possibility is to use probes labelled with fluorecent or luminescent markers (Matthews et al. 1985, Syvänen et al. 1986). Recently, HABILI et al. (1987) had encouraging results as they showed that BYDV, which occurs in low amounts in cereal foliage, can be 
effectively detected by using photobiotinlabelled cDNA probes. We conclude that even if probe-based assays are in their infancy, there is no doubt that they will develop towards such easy use as have immunochemical test kits.

\section{References}

Amasino, R. M. 1986. Acceleration of nucleic acid hybridization rate by polyethylene glycol. Anal. Biochem. 152: 304-307.

Barker, J. M., McInnes, J. L., Murphy, P. J. \& Symons, R. H. 1985. Dot-blot procedure with ${ }^{32} \mathrm{P}$ DNA probes for the sensitive detection of avocado sunblotch and other viroids in plants. J. Virol. Methods 10: 87-98.

Bar-Joseph, M., Segev, D., Twizer, S. \& Rosner, A. 1985. Detection of avocado sunblotch viroid by hybridization with synthetic oligonucleotide probes. J. Virol. Methods 10: 69-73.

-, Segev, D., Blickle, W., Yesodi, V., Franck, A. \& Rosner, A. 1986. Application of synthetic DNA probes for the detection of viroids and viruses. Developments and applications in virus testing, ed. Jones, R. C. C. \& Torrance, L. p. 13-23. Association of Applied Biologists, The Lavenham Press Ltd., Lavenham, Suffolk.

Baulcombe, D. C., Boulton, R. E., Flavell, R. B. \& JELLIS, G. J. 1984. Recombinant DNA probes for detection of viruses in plants. British Crop Prot. Conf. - Pests and diseases 1984: 207-213.

Boulton, R. E., Jell.is, G. J., Baulcombe, D. C. \& SquiRE, A. M. 1984. The practical application of complementary DNA probes to virus detection in a potato breeding programme. British Crop Prot. Conf. - Pests and diseases 1984: 177-180.

-, Jellis, G. J., Baulcombe, D. C. \& Squire, A. M. 1986. The application of complementary DNA probes to routine virus detection, with particular reference to potato viruses. Developments and applications in virus testing, ed. Jones, R. A. C. \& Torrance, L. p. 41-53. Association of Applied Biologists, The Lavenham Press Ltd., Lavenham, Suffolk.

Clark, M. F. \& Bar-Joseph, M. 1984. Enzyme immunosorbent assays in plant virology. Methods in virology VII, p. 51-85.

DeBokx, J. A. \& Cuperus, C. 1987. Detection of potato virus $\mathrm{Y}$ in early-harvested potato tubers by cDNA hybridization and three modifications of ELISA. EPPO Bull. 17: 73-79.

Fitts, R., Diamond, M., Hamilton, C. \& Neri, M. 1983. DNA-DNA hybridization assay for detection of Salmonella spp. in foods. Appl. Environ. Microbiol. 46: $1146-1151$.

Gallitelli, D. \& Hull, R. 1985. Preparation of complementary DNA by direct synthesis of plant virus RNAs from agarose gels. J. Virol. Methods 11: $141-144$
Garger, S. J. \& Turpen, T. H. 1986. Use of RNA probes to detect plant RNA viruses. Methods in Enzymology 118: 717-722.

Göbel, U. B. \& Standbridge, E. J. 1984. Cloned mycoplasma ribosomal RNA genes for the detection of mycoplasma contamination in tissue cultures. Science 226: $1211-1213$.

Gonzales, A., Prediger, E., Huecas, M. E., Nogueira, N. \& LizARDI, P. M. 1984. Minichromosomal repetitive DNA in Trypanosoma cruzi: Its use in a highsensitive parasite detection assay. Proc. Natl. Acad. Sci. USA 81: 3356-3360.

Goodwin, P. H. \& BantTARI, E. E. 1984. Increased sensitivity of ELISA for potato viruses $\mathrm{S}, \mathrm{X}$ and $\mathrm{Y}$ by polystyrene pretreatments, additives and a modified assay procedure. Plant Dis. 68: 944-947.

Gubler, U. \& Hoffman, B. J. 1983. A simple and very efficient method for generating cDNA libraries. Gene 25: 262-269.

Habilı, N., McInnes, J. L. \& Symons, R. H. 1987. Nonradioactive, photobiotin-labelled DNA probes for the routine diagnosis of barley yellow dwarf virus. J. Virol. Methods 16: 225-237.

Hammond, J. \& Hammond, R. W. 1985. A nucleic acid probe for detection of bean yellow mosaic virus. Acta Hortic. 164: 273-378.

Harrison, B. D., Robinson, D. J., Mowat, W. P. \& Duncan, G. H. 1983. Comparison of nucleic acid hybridization and other tests for detecting tobacco rattle virus in narcissus plants and potato tubers. Ann. Appl. Biol. 102: 331-338.

Hill, W. E., Payne, W. L., Zon, G. \& Moseley, S. L. 1985. Synthetic oligodeoxyribonucleotide probes for detecting heat-stable enterotoxin-producing Escherichia coli by DNA colony hybridization. Appl. Environ. Microbiol. 50: 1187-1191.

Hult, R. 1986. The potential for using dot-blot hybridization in the detection of plant viruses. Developments and applications in virus testing, ed. Jones, R. A. C. \& Torrance, L. p. 3-12. Association of Applied Biologists, The Lavenham Press Ltd., Lavenham, Suffolk.

— \& Davies, J. W. 1983. Genetic engineering with plant viruses, and their potential as vectors. Adv. Virus Res. 28: $1-33$.

Jablonski, E., Moomaw, E. W., Tullis, R. \& Ruth, J. L. 1986. Preparation of oligodeoxyribonucleotidealkaline phosphatase conjugates and their use as hybridization probes. Nucl. Acids Res. 14: 6115-6128. Jayasena, K. W., Randles, J. W. \& Barnett, O. W. 
1984. Synthesis of complementary DNA probe specific for detecting subterranean clover leaf virus in plants and aphids. J. Gen. Virol. 65: 109-117.

Koenig, R. \& Torrance, L. 1986. Antigenic analysis of potato virus $\mathrm{X}$ by means of monoclonal antibodies. J. Gen. Virol. 67: 2145-2151.

Leary, J. J., Brigati, D. J., WARd, D. C. 1983. Rapid and sensitive colorimetric method for visualizing biotinlabeled DNA probes hybridized to DNA or RNA immobilized on nitrocellulose: Bio-blots. Proc. Natl. Acad. Sci. USA 80: 4045-4049.

Lı, P., Medon, P. P., Skingle, D. C., Lanser, J. A. \& Srmons, R. H. 1987. Enzyme-linked synthetic oligonucleotide probes: non-radioactive detection of enterotoxigenic Escherichia coli in faecal specimens. Nucl. Acids Res. 15: 5275-5287.

Lin, H. J., WU, P.-C. \& LAI, C.-L. 1987. An oligonucleotide probe for the detection of hepatitis B virus DNA in serum. J. Virol. Methods 15: 139-149.

Matthews, J. A., Bathi, A., Hynds, C. \& Kricka, L. J. 1985. Enhanced chemiluminescent method for the detection of DNA dot-hybridization assays. Anal. Biochem. 151: 205-209.

Maule, A. J., Hull, R. \& Donson, J. 1983. The application of spot hybridization to the detection of DNA and RNA viruses in plant tissues. J. Virol. Methods 6: $215-224$.

Melton, D. A., Krieg, P. A., Rebagliati, M. R., Ma. niatis, T., Zinn, K. \& Green, M. R. 1984. Efficient in vitro synthesis of biologically active RNA and RNA hybridization probes from plasmids containing a bacteriophage SP6 promotor. Nucl. Acids Res. 12: 70357056.

Moreira, A., Jones, R. A. C. \& Fribourg, C. E. 1980. Properties of a resistance-breaking strain of potato virus X. Ann. Appl. Biol. 95: 93-103.

Owens, R. A. \& Diener, T. O. 1981. Sensitive and rapid diagnosis of potato spindle tuber viroid disease by nucleic acid hybridization. Science 213: 670-672.

- \& Diener, T. O. 1984. Spot hybridization for detection of viroids and viruses. Methods in Virology VII, p. $173-187$.

Morozov, S. YU., Zakhariev, V. M., Chernov, B. K., Prasolov, V. S., Koslov, YU. V., Atabekov, J. \& SKYABIN, K. G. 1983. The analysis of the primary structure and localization of the genes of envelope protein in the genetic RNA of potato virus X. Doklady Academii Nauk SSSR 271: 211-215 (in Russian).

Palukaitis, P. 1986. Preparation and use of $\mathrm{cDN}$ probes for detection of viral genomes. Methods in Enzymology 118: 723-742.

-, Cotrs, S. \& Zaituin, M. 1985. Detection and identification of viroids and viral nucleic acids by ndot-blot» hybridization. Acta Hortic. 164: 109-118.

Ranki, M., Palva, A., Virtanen, M., Laaksonen, M. \& Söderlund, H. 1983. Sandwich hybridization as a con- venient method for the detection of nucleic acids in crude samples. Gene 21: $77-85$.

-, Syvanen, A.-C. \& Sodzrlund, H. 1987. Nucleic acids in viral diagnosis. Laboratory diagnosis of infectious diseases, principles and practice, ed. Halonen, P. et al. In press. Springer-Verlag, Berlin.

Renz, M. \& KURZ, C. 1984. A colorimeteic method for DNA hybridization. Nucl. Acids Res. 12: 3435-3444.

Riesner, D. \& Gross, H. J. 1985. Viroids. Ann. Rev. Biochem. 54: 531-564.

Robinson, D. J., Harrison, B. D., Sequeira, J. C. \& Duncan, G. H. 1984. Detection of strains of African cassava mosaic virus by nucleic acid hybridization and some effects of temperature on their multiplication. Ann. Appl. Biol. 105: 483-493.

Rosner, A., RAccah, B., Mayoral, M. L. \& Bar-Joseph, M. 1986. Synthesis of DNA complementary to the polyadenylated genomic RNA of potato virus $\mathrm{Y}$ and its molecular cloning. Plant Pathol. 35: 178-184.

Saiki, R. K., Arnheim, N. \& Erlich, H. A. 1985. A - novel method for the detection of polymorphic restriction sites by cleavage of oligonucleotide probes: Application to sickle-cell anemia. BIO/Technology 3: 1008-1012.

Saiki, R. K., Scharf, S., Faloona, F., Mullis, K. B., Horn, G. T., Ernlich, H. A. \& Arnheim, N. 1985. Enzymatic amplification of $\beta$ globin genomic sequences and restriction site analysis for diagnosis of sickle cell anemia. Science 230: 1350-1354.

Sela, I., Reichman, M. \& Weissbach, A. 1984. Comparison of dot molecular hybridization and enzymelinked immunosorbent assay for detecting tobacco mosaic virus in plant tissue and protoplasts. Phytopath. 74: $385-389$.

SElf, C. H. 1985. Enzyme amplification - a general method applied to provide an immunoassisted assay for placental alkaline phosphatase. J. Immunol. Meth. 76: 389-393.

Skatnickı, A., Dale, J. G. \& Skatnickı, M. L. 1986. Detection of Fiji disease virus in infected sugarcane by nucleic acid hybridization. J. Virol. Methods 13: $71-77$.

SoINI, E. \& Kujala, H. 1983. Time-resolved fluorometer for lanthanide chelates - a new generation of nonisotopic immunoassays. Clin. Chem. 29: 65-68.

Symons, R. H. 1984. Diagnostic approaches for the rapid and specific detection of plant viruses and viroids. Plant - microbe interactions, Vol. 1, ed. Kosuge, T. \& Nester, E. W. p. 93-124. MacMillan, London.

Srvănen, A.-C. 1986. Nucleic acid hybridization: From research tool to routine diagnostic method. Medical Biology 64: 313-324.

-, Tchen, P., Ranki, M. \& Sóderlund, H. 1986. Timeresolved fluorometry: a sensitive method to quantify DNA-hybrids. Nucl. Acids Res. 14: 1017-1028.

TANAKA, K. \& IshiKawa, E. 1986. A highly sensitive bioluminescent assay of $\beta$-D-galactosidase from $E s$ - 
cherichia coli using 2-nitrophenyl- $\beta$-D-galactopyranoside. Anal. Lett. 19: 433-444.

Tchen, P., Fuchs, R. P. P., Sage, E. \& Leng, M. 1984. Chemically modified nucleic acids as immunodetectable probes in hybridization experiments. Proc. Natl. Acad. Sci. USA 81: 3466-3470.

Torrance, L., Larkins, A. P. \& Butcher, G. W. 1986. Characterization of monoclonal antibodies against potato virus $\mathrm{X}$ and comparison of serotypes with resistance groups. J. Gen. Virol. 67: 57-67.

Totten, P. A., Holmes, K. K., Handsfield, H. H.,
Knapp, J. S., Perine, P. L., Falkow, S. 1983. DNA hybridization technique for the detection of Neisseria gonorrhoeae in men with urethritis. J. Inf. Dis. 148; $462-471$.

VISCIDI, R. P. \& Yolken, R. G. 1987. Molecular diagnosis of infectious diseases by nucleic acid hybridization. Mol. Cell. Probes 1: 3-14.

Waterhouse, P. M., Gerlach, W. L. \& Miller, W. A. 1986. Serotypic-specific and general luteovirus probes from clones cDNA sequences of barley yellow dwarf virus. J. Gen. Virol. 67: 1273-1281.

\section{SELOSTUS}

\section{Kasvivirusten tunnistaminen nukleiinihappohybridisaatiolla}

\author{
Reijo Karjalainen \\ Kasvipatologian laitos, Helsingin yliopisto, \\ 00710 Helsinki
}

\section{Leo Rouhiainen}

Mikrobiologian laitos, Helsingin yliopisto, 00710 Helsinki

\section{Hans Söderlund \\ Geeniteknologian laboratorio, Orion-yhtymä Oy, Valimotie 7, 00380 Helsinki}

Geeniteknologia tarjoaa uuden keinon tunnistaa kasviviruksia niiden perintöaineksen perusteella. Tảtä pikadiagnostista menetelmää kutsutaan nukleiinihappohybridisaatioksi, koska se perustuu nukleiinihappomolekyylien puolikkaiden pariutumiseen. DNA-molekyyli koostuu kahdesta toisiaan tarkasti vastaavasta osasta, juosteesta, jotka toisistaan erotettuina pyrkivät pariutumaan uudelleen. Nukleiinihappohybridisaatiossa tunnistin eli koetin on tunnistettavan patogeenin nukleiinihappomolekyylin keinotekoinen puolikas, toinen juoste. Kasvinăytteessä olevien virusten nukleiinihapot 'halkaistaan' yksijuosteisiksi kuumentamalla ja kiinnitetaaăn erikoissuodattimelle, nitroselluloosafiltterille. Tähän lisătäăn koetinjuosteet, jotka pariutuvat vastaavan puolikkaansa kanssa, mikăli niită on näytteessä, eli mikäli kasvi on viruksen infektoima. Pariutuminen havaitaan esimerkiksi autoradiografisesti, tuikelaskimella tai entsymaattisten vărireaktioiden perusteella. Tässă kirjoituksessa tarkastellaan nukleiinihappohybridisaation kehitysnäkymiă kasvivirusten tunnistamisessa sekä kuvataan sen työvaiheet kăyttăen perunan X-virusta (PVX) testiviruksena.

Nukleiinihappohybridisaatiossa tarvittavien koetinmolekyylien valmistamiseksi puhdistettiin ensin perunan X- virus ja eristettiin sen RNA. Tämän jălkeen syntetoitiin toista juostetta vastaava eli komplementaarinen DNAjuoste (cDNA) spesifisten entsyymien avulla. Kaksisāikeiset komplementaariset DNA-molekyylit pilkottiin tämän jälkeen Sau3-restriktioentsyymillä ja kloonattiin pBR322-plasmidiin BamHI-alueelle. Yhdistelmä-DNA -molekyylejä eli PVX:n nukleiinihappoa sisăltävăt bakteeripesäkkeet tunnistettiin antibioottimarkkerien avulla, ja valitut koetinmolekyylit leimattiin radioaktiivisella ${ }^{32} \mathrm{P}$ :llä nick-translaation avulla. Hybridisaatiota varten $2 \mu \mathrm{l}$ puhdistamatonta perunan tai tupakan mehua tai puhdistettua virusta pipetoitiin nitroselluloosafiltterille, joka oli ensin käsitelty $20 \times \mathrm{SSC}$-puskurissa. Tämăn jălkeen nukleiinihapot kiinnitettiin filtterille kuumentamalla sită $80^{\circ} \mathrm{C}$ :ssa kaksi tuntia. Tămăn jălkeen filtterit esihybridisoitiin muovipusseissa 4-5 tuntia, minkä jälkeen koetin lisăttiin varsinaiseen hybridisaatioliuokseen ja hybridisaation annettiin jatkua $50^{\circ} \mathrm{C}$ :ssa 16 tuntia. Hybridisoinnin jălkeen suodattimet pestiin useaan kertaan puskurissa, jolloin hybridisoitumaton leima huuhtoutui pois.

Tulokset osoittivat, että PVX:n RNA:sta kloonatuilla koettimilla pystyttiin tunnistamaan $1 \mathrm{ng}$ puhdasta virusta $2 \mu \mathrm{l}$ pisarassa. Koettimien avulla voitiin myös no- 
peasti ja luotettavasti tunnistaa PVX:n infektoimat mehunäytteet suodattimelta, sillä koettimet reagoivat vain virusta sisăltävien näytteiden kanssa. Nämä hybridisaatiotulokset tukevat viimeaikaisia DNA-diagnostiikkatutkimuksia, joiden mukaan tämän tekniikan avulla voidaan tarkasti ja luotettavasti tunnistaa monia viruksia. Monien virusten tunnistuksessa DNA-tekniikka on ELISAa herkempi ja nopeampi, joskin ELISA on toistaiseksi paljon yksinkertaisempi ja helpompi. Nopeuden ja tarkkuuden vuoksi nukleiinihappohybridisaatiota kuitenkin kăytetaaăn jo laajalti perunan jalostuksessa seulomalla sillă nopeasti virusta kestăvăt kloonit jalostusaineistoista. Nukleiinihappohybridisaatio soveltuu parhaiten sellaisten virusten tunnistamiseen, joihin ELISA ja muut serologiset menetelmăt eivăt sovellu, kuten viruksiin, jotka ovat kasvissa pienină pitoisuuksina, joilla on huonot antigeeniset ominaisuudet, jotka sisältảvät satelliitteja ja joiden genomi on moniosainen. Tällaisia viruksia on hyvin paljon, ja ne ovat hyvin haitallisia sekă maa- ettă puu- tarhataloudessa.

Nukleiinihappohybridisaation käyttöă rajoittaa toistaiseksi eniten se, ettă tunnistuksessa tarvittavat koettimet on leimattava radioaktiivisesti, mikä on kallista ja edellyttäả erikoistiloja. Nukleiinihappohybridisaatio on kuitenkin hyvin uusi menetelmä, ja ei-radioaktiivisista koettimista on jo saatu lupaavia tuloksia. On myös kehitetty uusia hybridisaatiomenetelmiä, jotka soveltuvat entistă paremmin automatisoitaviksi. Kerroshybridisaatio on Suomessa kehitetty menetelmă (Orion-yhtymă Oy), jolla mikrobeja voidaan tunnistaa helposti puhdistamatta näytettä. Nukleiinihappohybridisaatiomenetelmăt ovat nopeasti kehittymässă siihen suuntaan, että niillä voidaan tehostaa monien tăllä hetkellă vaikeasti tunnistettavien kasvivirusten, viroidien ja kasvipatogeenisten bakteerien diagnostiikkaa. Tămă uusi menetelmă tulee lăhivuosina helpottamaan esimerkiksi kasvintarkastustoimintaa, terveen kasvimateriaalin tuotantoa ja taudinkestävyysjalostusta. 